\title{
Emprego da RT-PCR em tempo real para a quantificação da expressão de genes associados à resposta imune em bezerros bovinos experimentalmente infectados por Neospora caninum
}

\author{
Use of the real time RT-PCR for immune related gene expression quantitation \\ in experimentally infected Neospora caninum bovine calves \\ Sandra Mayumi Nishi1 ${ }^{12 *}$; Luciana Mori Viero ${ }^{3}$; Rodrigo Martins Soares ${ }^{1}$; \\ Paulo Cesar Maiorka ${ }^{4}$; Solange Maria Gennari ${ }^{1}$
}

\begin{abstract}
${ }^{1}$ Departamento de Medicina Veterinária Preventiva e Saúde Animal, Faculdade de Medicina Veterinária e Zootecnia - FMVZ, Universidade de São Paulo - USP

${ }^{2}$ Departamento de Medicina Veterinária Preventiva e Saúde Animal, Faculdade de Medicina Veterinária e Zootecnia - FMVZ, Universidade de Sáo Paulo - USP e Bolsista Jovem Pesquisador FAPESP 05/04455-6

${ }^{3}$ Departamento de Parasitologia, Instituto de Ciências Biomédicas - ICB, Universidade de São Paulo - USP e Bolsista FAPESP 06/00197-5

${ }^{4}$ Departamento de Patologia, Faculdade de Medicina Veterinária e Zootecnia - FMVZ, Universidade de Sáo Paulo - USP

Recebido em 31 de Maio de 2008

Aceito em 27 de Fevereiro de 2009
\end{abstract}

\section{Resumo}

Neospora caninum é um dos principais agentes causadores de abortamentos e natimortalidade em bovinos. A defesa imune do hospedeiro é capaz de inibir a atividade dos taquizoítos na fase aguda da infecção, mas não age sobre os bradizoítos nos cistos teciduais. A ativação e a modulação dessa resposta de defesa são controladas por mediadores celulares. A técnica do RT-PCR em tempo real foi empregada para a detecçáo de alguns desses mediadores durante a infecção pelo $N$. caninum. Foram analisadas amostras de linfonodos poplíteos, fígado e córtex cerebral de bezerros Holandeses e Nelores infectados com taquizoítos por via intramuscular e controles não-infectados, abatidos no sexto dia pós-inoculação. A RT-PCR em tempo real detectou a expressão dos genes em todos os tecidos analisados. Não houve variaçấo significativa na expressão do gene GADPH entre os grupos, a eficiência de amplificação desse foi similar aos demais genes testados e foi empregado como controle endógeno na análise. A comparação entre infectados e não-infectados permitiu a quantificação relativa da expressão gênica. A expressão dos genes IFN- $\gamma$ e TNF- $\alpha$ apresentou elevação significante em algumas amostras. Os genes iNOS e TGF- $\beta 1$ apresentaram algumas variaçóes não-significativas e os valores de IL-4 e IL-10 permaneceram praticamente inalterados.

Palavras-chave: Neospora caninum, Bos taurus, Bos indicus, RT-PCR, expressão gênica.

\footnotetext{
Abstract

*Autor para correspondência: Sandra Mayumi Nishi

Departamento de Medicina Veterinária Preventiva e Saúde Animal, Faculdade de Medicina Veterinária e Zootecnia - FMVZ, Universidade de São Paulo - USP, Av. Prof. Dr. Orlando Marques de Paiva, 87, Cidade Universitária, CEP 05508-270 São Paulo - SP, Brasil, e-mail: smnishi@usp.br
}

Neospora caninum is one of the main causes of abortion and natimortality in cattle. Host immune defense is capable to inhibit tachyzoite activity during acute infection, but there is no action against bradyzoites in tissue cysts. Activation and modulation of this response is controlled by cell mediators. The real-time RT-PCR technique was employed to detect some of those mediators during $N$. caninum infection. Holstein and Nelore calves intramuscularly infected with tachyzoites and uninfected controls were slaughtered at the sixth day post-infection and popliteal lymph node, liver and brain cortex samples were analyzed. Real-time RT-PCR detected gene expression in all tissues. No significant variation of GAPDH gene expression was detected among groups, its amplification efficiency was similar to the other genes tested and it was used as the endogenous control for the analysis. Comparisons between infected and uninfected groups allowed the relative gene expression quantification. IFN- $\gamma$ and TNF- $\alpha$ genes showed increased expression in some samples. iNOS and TGF- $\beta 1$ genes had some non-significant variations and IL- 4 and IL-10 stayed pratically inaltered.

Keywords: Neospora caninum, Bos taurus, Bos indicus, RT-PCR, gene expression. 


\section{Introdução}

A infecção por Neospora caninum é considerada umas das principais causas de abortamentos e natimortalidade em rebanhos bovinos no mundo (DUBEY et al., 2007). Com base em dados soro-epidemiológicos recentes, sabe-se que a ocorrência da neosporose varia de 8,8 a 46,0\% nos rebanhos nacionais, afetando tanto o gado leiteiro quanto o de corte e é encontrado em praticamente todos os estados pesquisados (AGUIAR et al., 2006; CORBELLINI et al., 2002; DUBEY et al., 2007; GONDIM et al., 1999; GUIMARÁES et al., 2004; MELO et al., 2006; MINERVINO et al., 2008; MUNHOZ et al., 2006; OSHIRO et al., 2007).

É difícil estimar os prejuízos causados pela infecção por $N$. caninum. Os principais danos manifestam-se durante o período gestacional pela ocorrência de abortamentos, elevada natimortalidade ou pela geraçáo sucessiva de bezerros congenitamente infectados que pode se repetir ao longo de várias gestaçôes (DUBEY et al., 2007; INNES et al., 2007).

Em sua fase inicial, a infecção se dissemina de forma sistêmica e o parasito se reproduz rapidamente em vários tecidos. Em hospedeiros imunologicamente competentes, a ativação da resposta celular controla a multiplicação parasitária de forma eficiente, entretanto não é capaz de eliminar os parasitos que se mantêm latentes em cistos que se localizam preferencialmente em tecido nervoso. Dessa maneira, uma vez infectado, o bovino assume a condição de portador são. Em períodos de diminuição da defesa imune do hospedeiro, como ocorre durante a gestação, $N$. caninum retorna à atividade, possibilitando a transmissão transplacentária da infecção (HEMPHILL et al., 2006).

Os mecanismos envolvidos na defesa dos hospedeiros contra os parasitos são bastante complexos e envolvem vários tipos celulares. A ativação e o controle dessa resposta são feitos por mediadores celulares que são produzidos de acordo com o agente agressor envolvido. Na medicina veterinária, o custo do desenvolvimento de métodos detecção e produção de imunoreagentes espécie específicos para cada mediador tornaram-se um grande empecilho para o estudo da resposta imune celular.

No presente experimento, a técnica da PCR em tempo real foi testada para a detecção e quantificação da expressão de mRNA de alguns destes mediadores em resposta à infecção por $N$. caninum. Para tanto, foram avaliados diferentes tecidos de bezerros das raças Nelore e Holandês infectados por $N$. caninum e controles sem infecção.

Foram selecionados mediadores celulares envolvidos na resposta contra parasitos intracelulares (interferon gama, IFN- $\gamma$ ), mediadores implicados no processo inflamatório (fator de necrose tumoral alfa, TNF- $\alpha$ ), outros de ação desconhecida contra $N$. caninum, mas conhecidos por estar associados a funçóes importantes de fagócitos contra Toxoplasma gondii como o óxido nítrico sintase induzível (iNOS), implicados na resposta Th2 (interleucina 4, IL-4), moduladores da resposta inflamatória (IL-10, fator transformador de crescimento beta 1, TGF- $\beta 1$ ) e um gene constitutivo gliceraldeído fosfato desidrogenase (GAPDH).
Conjuntos de primers e sondas específicos para bovinos foram desenhados a partir de sequências disponibilizadas no Genbank. A eficiência das amplificaçóes foi avaliada por meio da linearidade e da inclinação das curvas padrão frente a diferentes concentraçóes de cDNA-alvo (Applied Biosystems, 2004).

\section{Material e Métodos}

\section{Animais}

Foram utilizados catorze bovinos, sete da raça Holandesa e sete da raça Nelore, sorologicamente negativos para $N$. caninum e com idade aproximada de seis meses. Todos os bezerros foram mantidos em instalaçóes sem acesso a pasto, em grupos de três a quatro bezerros por baia, diariamente alimentados com feno e ração própria para bezerros e água ad libitum em conformidade com os princípios éticos de experimentação animal da Comissão de Bioética da FMVZ - USP (protocolo no 814/2005).

\section{Infeç̧ão por Neospora caninum e obtençâo das amostras de tecido}

Quatro bezerros Holandeses e quatro Nelores receberam uma suspensão contendo $10^{8}$ taquizoítos de $N$. caninum obtidos de cultivos celulares (cepa NC-1) por via IM no membro posterior e três bezerros de cada raça foram mantidos como controle sem infecção e receberam uma suspensão de células Vero pela mesma via. No sexto dia pós-infecção os bezerros foram abatidos para a remoção das amostras de linfonodo poplíteo ipsi e contralateral à inoculação, córtex cerebral e fígado que foram imediatamente imersas em nitrogênio líquido. As amostras de tecido permaneceram congeladas a $-70{ }^{\circ} \mathrm{C}$ até o momento das extrações de RNA.

\section{Desenho de "primers" e sondas}

Sequências dos genes-alvo foram obtidas do Genbank e exportadas para o programa Primer Express v 3.3 (Applied Biosystems). Os conjuntos de primers e sonda foram desenhados seguindo os critérios padróes definidos pelo software para sondas do tipo TaqMan. Para o gene IFN- $\gamma$ foi escolhido uma sonda do tipo MGB devido a ausência de uma sequência adequada para o desenho de uma sonda TaqMan.

Os pares de primers e as respectivas sondas fluorogênicas foram sintetizadas pela Applied Biosystems de acordo com a listagem apresentada no Quadro 1.

\section{Extração de RNA}

As amostras de tecido foram inicialmente fragmentadas em grau com pistilo contendo nitrogênio líquido. A seguir foram misturadas ao reagente Trizol (Invitrogen) com auxílio de um homogenizador de tecidos (MA102, Marconi). A extraçáo de RNA foi realizada seguindo as instruçóes do fabricante. 
Quadro 1. Genes testados pela técnica de RT-PCR em tempo real, número de acesso no Genbank, sequência dos conjuntos de primers e sondas $\left(5^{\prime} \rightarrow 3^{\prime}\right)$ empregados na reação de amplificação e respectivas marcaçôes das sondas, São Paulo, 2007.

\begin{tabular}{|c|c|c|}
\hline Gene-alvo & Número de acesso & Primers senso (1) e anti-senso (2) e sonda (3) \\
\hline IFN- $\gamma$ & NM_174086 & $\begin{array}{l}\text { (1) GGAGGACTTCAAAAAGCTGATTCA } \\
\text { (2) GGCTTTGCGCTGGATCTG } \\
\text { (3) VIC-ATTCCGGTGGATGATC-MGB }\end{array}$ \\
\hline TNF- $\alpha$ & AF011927 & $\begin{array}{l}\text { (1) CTCAGTCGTGCCCGACACT } \\
\text { (2) CATGGATGGAGGAGCTTGGT } \\
\text { (3) VIC-TGCGACCCCATGGACAGTAGCCTG-TAMRA }\end{array}$ \\
\hline iNOS & U18331 & $\begin{array}{l}\text { (1) GAGGTGCACACCGCCTATTC } \\
\text { (2) TGCCGCAGGATGTCTTGAA } \\
\text { (3) 6-FAM-CGCCTGCCTGACCAGCCCA-TAMRA }\end{array}$ \\
\hline IL-4 & M77120 & $\begin{array}{l}\text { (1) GCTGCCTGTAGCAGACGTCTT } \\
\text { (2) GGAGGACTTCAAAAAGCTGATTCA } \\
\text { (3) VIC-TGCCCCAAAGAACACAACTGAGAAGGA-TAMRA }\end{array}$ \\
\hline IL-10 & NM_174088 & $\begin{array}{l}\text { (1) CCTTGTCGGAAATGATCCAGTT } \\
\text { (2) TTCACGTGCTCCTTGATGTCA } \\
\text { (3) 6-FAM-CCACAGGCTGAGAACCACGGG-TAMRA }\end{array}$ \\
\hline TGF- $\beta 1$ & M36271 & $\begin{array}{l}\text { (1) CGAGCCCTGGACACCAACTA } \\
\text { (2) GGAAGTCAATGTAGAGCTGACGAA } \\
\text { (3) 6-FAM-TGCTTCAGCTCCACAGAAAAGAACTGCTG-TAMRA }\end{array}$ \\
\hline GAPDH & BC102589 & $\begin{array}{l}\text { (1) GGCGCCAAGAGGGTCAT } \\
\text { (2) GTGGTTCACGCCCATCACA } \\
\text { (3) 6-FAM-TCTCTGCACCTTCTGCCGATGCC-TAMRA }\end{array}$ \\
\hline
\end{tabular}

A concentração e a qualidade do RNA foram estimadas por leitura em espectrofotômetro a $260 \mathrm{~nm}$ e cálculo da razão 260/280, respectivamente (Biophotometer, Eppendorf).

\section{Sintese de $c D N A$}

As amostras de RNA foram tratadas com Dnase (Deoxyribonuclease I, Invitrogen) para remoção de possíveis resíduos de DNA genômico. A seguir, a reação de transcrição reversa foi realizada utilizando $2 \mu \mathrm{g}$ de RNA total, transcriptase reversa (Superscript III, Invitrogen) e Oligo dT(12-18) primer (Invitrogen) em presença de inibidores de Rnase (Rnase OUT, Invitrogen) em um volume final de $20 \mu \mathrm{L}$, a ordem e as etapas de incubação foram realizadas de acordo com as recomendaçóes de tempo e temperaturas do fabricante dos reagentes.

\section{PCR em tempo real}

As amplificaçôes por PCR foram realizadas em duplicatas e utilizando $50 \mathrm{ng}$ de cDNA por reação. As reaçôes foram preparadas com reagentes padronizados para PCR em tempo real (TaqMan Universal PCR Master Mix, Applied Biosystems) adicionado dos conjuntos de primers e sonda específico para cada gene. As condiçôes da reação foram $50{ }^{\circ} \mathrm{C}$ durante 2 minutos, $95^{\circ} \mathrm{C}$ durante 10 minutos e 40 repetiçóes de $95^{\circ} \mathrm{C}$ por 15 segundos e $60{ }^{\circ} \mathrm{C}$ por 1 minuto. As leituras da fluorescência foram realizadas pelo equipamento 7500 Real-Time PCR (Applied Biosystems) a cada ciclo de amplificação e, posteriormente, analisados pelo Sequence Detection Software (SDS) v1.3 (Applied Biosystems).
Todas as reaçóes foram submetidas às mesmas condiçóes de análise e normalizadas pelo sinal do corante de referência passiva ROX para correção de flutuaçóes na leitura decorrentes a variaçóes de volume e evaporação ao longo da reação. $\mathrm{O}$ resultado, expresso em valor de CT, se refere ao número de ciclos de PCR necessários para que o sinal o fluorescente atinja o limiar de detecção.

Os resultados individuais expressos em valores de CT foram a seguir transferidos para planilhas e agrupados de acordo com o tecido analisado, a raça e a condição infectado ou não-infectado para realização da análise estatística.

\section{Eficiência de amplificação}

Com o intuito de avaliar a eficiência da reação de amplificação de cada gene-alvo, foram realizadas diluiçóes seriadas de cDNA que foram submetidas à amplificação nas mesmas condiçóes acima citadas. O gráfico gerado pela concentração de cDNA e os respectivos valores de CT foram empregados para o cálculo da equação de regressão e a correlação entre as variáveis pelo R-quadrado.

\section{Eletroforese em gel de agarose}

$\mathrm{Na}$ fase de inicial de padronização da reação de PCR em tempo real, o produto das reaçóes de PCR foram submetidas a eletroforese em gel de agarose a $2 \%$ e corados com brometo de etídio para a visualização e a confirmação da amplificação de um único produto em tamanho compatível com o esperado. 


\section{Análise estatística}

Os resultados da PCR em tempo real para cada gene foram agrupados de acordo com a raça e a condiçáo infectado ou não-infectado e submetidos à análise de variância e comparados pelo teste $t$ de Student $(\alpha=0,05)$.

\section{Resultados e Discussáo}

A técnica da RT-PCR em tempo real permite a quantificação da expressão de genes induzidos em resposta a diferentes condiçóes, apresentando um maior grau de sensibilidade que o PCR competitivo e uma boa reprodutibilidade. A quantificação da expressão dos genes é feita de forma relativa, isto é, pela comparação da expressão em um grupo exposto a um estímulo a um outro grupo não exposto, denominado grupo controle (ZARLENGA; HIGGINS, 2001).

Inicialmente, os produtos da reação de PCR em tempo real foram submetidos a eletroforese em gel de agarose confirmando a amplificação do gene-alvo pela geração de um único produto de tamanho compatível com o esperado e a ausência de formação de produtos inespecíficos. Os resultados qualitativos, isto é, a presença de fluorescência na PCR em tempo real e a visualização do produto na eletroforese em gel de agarose e a ausência de fluorescência e a não visualização de banda, foram concordantes.

A partir dos dados colhidos pelo equipamento, o programa SDS v 1.3 (Applied Biosystems) realiza o cálculo automático do limiar de detecção. Entretanto, objetivando uma melhor análise dos dados optou-se pela verificação individual das curvas de amplificação, remoção dos sinais não-específicos e o ajuste manual do limiar de detecção para que os resultados fossem obtidos na faixa de amplificação exponencial. Definiu-se, dessa maneira, um limiar de detecção distinto para cada gene testado.

A seguir, para validar a quantificação relativa da expressão de mRNA dos tecidos é importante que todas as reações de PCR ocorram sob condiçóes ótimas e similares. Para testar a eficiência de amplificação de cada um dos genes-alvo, diluiçóes seriadas de cDNA foram testadas e os resultados da reação (dados pelo valor de CT) foram tabeladas para o cálculo da equação de regressão e do R-quadrado.

As equaçôes de regressão obtidas estão listadas na Tabela 1 e mostram boas condiçôes de amplificação (valores de inclinação entre 2,8 e 3,3) e correlação positiva entre as variáveis ( $\mathrm{R}^{2}$ entre 0,86 e $0,99)$ observadas em pelo menos quatro diluiçôes sucessivas.

$\mathrm{O}$ uso de um gene constitutivo como controle endógeno na reação de PCR quantitativo e como fator de normalização dos dados é controverso (BUSTIN, 2002; THELLIN et al., 1999). Um dos requisitos mais importantes para a escolha de um gene candidato a controle endógeno é a sua presença constante em todas as amostras testadas com pouca variação na expressão por influência de estímulos externos ou mudanças no metabolismo celular. Seguindo esse raciocínio, as flutuaçóes decorrentes a variaçóes de pipetagem e consequentemente na concentração final dos reagentes, da amostra ou variaçóes nas condiçóes das reaçóes de RT ou de PCR seriam corrigidas pela expressão do gene constitutivo (APPLIED BIOSYSTEMS, 2004).
No presente experimento, o gene GAPDH foi detectado em quantidade similar em todos os animais experimentais, sem apresentar uma diferença estatística significante (teste $t$ de Student, $\alpha=0,05)$ entre os valores médios dos grupos controle e infectado, assim como, entre os bezerros da raça Nelore e Holandesa (Tabela 2).

Essa ausência de variação na expressão do gene controle endógeno também pode ser interpretada como um indicador da integridade do RNA extraído, da adequada síntese de cDNA na reação de transcrição reversa e da boa amplificação do produto durante a PCR. Além desses fatores, o gene GAPDH apresentou eficiência de amplificação semelhante aos demais genes testados (Tabela 1).

Devido a diferenças na composição celular e na função metabólica dos tecidos de linfonodo, de fígado e de córtex cerebral não foi realizado uma comparação nos níveis de expressão entre um tipo tecidual e outro.

Com base nesses resultados e com o intuito de corrigir possíveis variaçóes na quantidade de RNA inicial empregada em cada reação, assim como variaçóes decorrentes da pipetagem manual dos reagentes, optou-se pela utilização do gene controle endógeno (BUSTIN et al., 2005). Dessa maneira, a quantificação da expressão dos genes IFN- $\gamma$, TNF- $\alpha$, iNOS, IL-4, IL-10 e TGF- $\beta 1$ foram expressos em valores de $\Delta \mathrm{CT}$ (Tabela 3), utilizando a expressão do gene GAPDH como fator de normalização.

Similarmente ao observado no gene GAPDH, a técnica da RT-PCR em tempo real detectou a expressão dos demais genesalvo em todos os tecidos analisados. Os resultados indicam uma alteração na expressão de alguns desses genes nos bezerros infectados por $N$. caninum.

A infecção por $N$. caninum é pouco patogênica para bovinos imunologicamente competentes. As lesões mais frequentemente descritas são observadas em vacas gestantes na interface materno-fetal e nos tecidos fetais (INNES et al., 2005). Com base em infecçóes experimentais em cultivos celulares (INNES et al., 1995; YAMANE et al., 2000) e em camundongos (KHAN, et al., 1997; LONG et al., 1998; RETTIGNER et al., 2004; RITTER et al., 2002), sabe-se que a resposta celular mediada pelo IFN- $\gamma$ é um importante componente no controle da infecção por taquizoítos.

No presente experimento, os bezerros foram abatidos no sexto dia pós-infecção com intuito de detectar alteraçóes na expressão de genes induzidas pelos taquizoítos durante a fase inicial de ativação da resposta do hospedeiro.

Tabela 1. Equação de regressão e R-quadrado $\left(\mathrm{R}^{2}\right)$ das reações de amplificaçâo de cada gene-alvo, São Paulo, 2007.

\begin{tabular}{lcc}
\hline Gene & Equaçáo de regressão & $\mathbf{R}^{2}$ \\
\hline IFN- $\gamma$ & $\mathrm{y}=-3,368 \mathrm{x}+36,30$ & 0,981 \\
TNF- $\alpha$ & $\mathrm{y}=-2,281 \mathrm{x}+25,87$ & 0,992 \\
INOS & $\mathrm{y}=-3,184 \mathrm{x}+38,56$ & 0,864 \\
IL-4 & $\mathrm{y}=-2,896 \mathrm{x}+36,58$ & 0,953 \\
IL-10 & $\mathrm{y}=-2,821 \mathrm{x}+29,74$ & 0,993 \\
TGF- $\beta 1$ & $\mathrm{y}=-2,290 \mathrm{x}+30,40$ & 0,995 \\
GAPDH & $\mathrm{y}=-3,124 \mathrm{x}+24,26$ & 0,995 \\
\hline
\end{tabular}


Tabela 2. Expressão do gene GAPDH em diferentes tecidos de bezerros da raça Nelore e Holandesa pela técnica da RT-PCR em tempo real. Média e desvio-padrão dos valores de CT obtidos nas amostras de linfonodos poplíteos (LN pop) ipsi e contralateral à inoculação, córtex cerebral e fígado nos grupos infectados com N. caninum e controles sem infecção, São Paulo, 2007.

\begin{tabular}{cccccc}
\hline \multirow{2}{*}{ Raça } & Grupo & \multicolumn{4}{c}{ Tecido } \\
\cline { 3 - 6 } & & LN pop ipsilateral & LN pop contralateral & Córtex & Fígado \\
\hline \multirow{2}{*}{ Holandês } & Controle & $20,4 \pm 1,1^{\mathrm{a}}$ & $21,5 \pm 2,5^{\mathrm{a}}$ & $18,3 \pm 0,6^{\mathrm{a}}$ & $22,2 \pm 1,9^{\mathrm{a}}$ \\
& Infectado & $19,7 \pm 1,7^{\mathrm{a}}$ & $20,3 \pm 2,6^{\mathrm{a}}$ & $18,5 \pm 0,6^{\mathrm{a}}$ & $24,7 \pm 1,2^{\mathrm{a}}$ \\
\multirow{2}{*}{ Nelore } & Controle & $21,6 \pm 0,5^{\mathrm{a}}$ & $20,1 \pm 2,1^{\mathrm{a}}$ & $18,6 \pm 1,8^{\mathrm{a}}$ & $24,7 \pm 3,5^{\mathrm{a}}$ \\
& Infectado & $21,3 \pm 2,1^{\mathrm{a}}$ & $22,3 \pm 3,0^{\mathrm{a}}$ & $19,5 \pm 1,1^{\mathrm{a}}$ & $26,4 \pm 3,9^{\mathrm{a}}$ \\
\hline
\end{tabular}

Letras distintas entre grupos indicam diferença estatística significativa $(\alpha=0,05)$.

Tabela 3. Expressão dos genes IFN- $\gamma$, IL-10, IL-4, iNOS, TGF- $\beta 1$ e TNF- $\alpha$ em amostras de linfonodo poplíteo ipsilateral (LN ipsilat), contralateral (LN contralat), fígado e córtex cerebral de bezerros das raças Holandesa (Hol) e Nelore (Nel). Valores médios de $\Delta \mathrm{CT}$ para os grupos infectados (I) com N. caninum e controles sem infecçáo (C) de acordo com a raça, Sáo Paulo, 2007.

\begin{tabular}{|c|c|c|c|c|c|c|c|}
\hline \multirow{2}{*}{ Tecido } & \multirow{2}{*}{ Grupo } & \multicolumn{6}{|c|}{ Genes-alvo } \\
\hline & & IFN- $\gamma$ & TNF- $\alpha$ & iNOS & IL-4 & IL-10 & TGF- $\beta 1$ \\
\hline \multirow{3}{*}{$\begin{array}{l}\mathrm{LN} \\
\text { ipsilateral }\end{array}$} & Hol-C & $8,6 \pm 0,6^{\mathrm{ab}}$ & $8,0 \pm 0,3^{\mathrm{ab}}$ & $9,3 \pm 0,6^{a}$ & $11,5 \pm 0,6^{a}$ & $8,2 \pm 0,6^{a}$ & $5,6 \pm 0,3^{\mathrm{ab}}$ \\
\hline & Hol-I & $7,3 \pm 1,4^{\mathrm{b}}$ & $8,3 \pm 0,3^{a}$ & $10,3 \pm 0,7^{\mathrm{a}}$ & $11,0 \pm 0,8^{\mathrm{a}}$ & $7,7 \pm 0,4^{a}$ & $5,0 \pm 0,0^{b}$ \\
\hline & Nel-C & $10,6 \pm 2,0^{\mathrm{a}}$ & $7,1 \pm 0,7^{b}$ & $8,9 \pm 0,9^{\mathrm{a}}$ & $11,1 \pm 0,6^{\mathrm{a}}$ & $8,1 \pm 0,9^{\mathrm{a}}$ & $5,0 \pm 0,5^{\mathrm{ab}}$ \\
\hline \multirow{4}{*}{$\begin{array}{l}\text { LN } \\
\text { contralat }\end{array}$} & Hol-C & $8,1 \pm 0,5^{\mathrm{a}}$ & $7,1 \pm 0,4^{a}$ & $9,5 \pm 1,1^{\mathrm{a}}$ & $11,4 \pm 1,2^{\mathrm{a}}$ & $7,5 \pm 0,9^{\mathrm{a}}$ & $6,3 \pm 1,0^{\mathrm{a}}$ \\
\hline & Hol-I & $8,7 \pm 0,3^{\mathrm{a}}$ & $7,8 \pm 0,8^{\mathrm{a}}$ & $10,0 \pm 1,4^{a}$ & $11,4 \pm 0,6^{a}$ & $7,7 \pm 0,1^{a}$ & $5,3 \pm 0,9^{a}$ \\
\hline & Nel-C & $10,7 \pm 1,0^{\mathrm{b}}$ & $7,4 \pm 1,1^{a}$ & $10,6 \pm 1,5^{a}$ & $11,8 \pm 1,3^{\mathrm{a}}$ & $8,3 \pm 0,4^{a}$ & $5,6 \pm 0,3^{a}$ \\
\hline & Nel-I & $8,0 \pm 1,1^{\mathrm{a}}$ & $7,3 \pm 1,1^{\mathrm{a}}$ & $9,0 \pm 1,6^{\mathrm{a}}$ & $11,4 \pm 0,5^{\mathrm{a}}$ & $9,3 \pm 0,4^{\mathrm{b}}$ & $6,4 \pm 0,6^{\mathrm{a}}$ \\
\hline \multirow{2}{*}{ Córtex } & Nel-C & $16,8 \pm 1,5^{\mathrm{a}}$ & $9,1 \pm 0,6^{\mathrm{ab}}$ & $12,7 \pm 1,9^{\mathrm{a}}$ & $19,6 \pm 1,9^{a}$ & $14,5 \pm 2,1^{\mathrm{c}}$ & $9,6 \pm 0,8^{\mathrm{a}}$ \\
\hline & Nel-I & $16,8 \pm 1,3^{\mathrm{a}}$ & $9,7 \pm 0,4^{a}$ & $11,5 \pm 0,9^{\mathrm{a}}$ & $18,8 \pm 0,4^{a}$ & $14,2 \pm 1,2^{b c}$ & $9,5 \pm 0,1^{\mathrm{a}}$ \\
\hline \multirow{4}{*}{ Fígado } & Hol-C & $9,7 \pm 2,0^{\mathrm{a}}$ & $9,8 \pm 0,2^{\mathrm{ab}}$ & $12,3 \pm 0,6^{a}$ & $15,9 \pm 1,3^{\mathrm{a}}$ & $9,9 \pm 0,8^{a}$ & $8,8 \pm 0,2^{\mathrm{ab}}$ \\
\hline & Hol-I & $7,5 \pm 3,3^{\mathrm{a}}$ & $9,4 \pm 0,7^{\mathrm{ab}}$ & $10,9 \pm 1,0^{\mathrm{a}}$ & $15,1 \pm 1,5^{a}$ & $9,6 \pm 1,1^{\mathrm{a}}$ & $9,0 \pm 1,3^{\mathrm{ab}}$ \\
\hline & Nel-C & $10,6 \pm 1,4^{\mathrm{a}}$ & $10,3 \pm 0,8^{\mathrm{a}}$ & $11,8 \pm 1,9^{\mathrm{a}}$ & $14,1 \pm 0,2^{\mathrm{a}}$ & $11,6 \pm 0,9^{\mathrm{b}}$ & $8,0 \pm 0,3^{b}$ \\
\hline & Nel-I & $8,1 \pm 1,5^{a}$ & $8,2 \pm 1,7^{\mathrm{b}}$ & $11,9 \pm 1,0^{\mathrm{a}}$ & $15,1 \pm 2,3^{\mathrm{a}}$ & $11,9 \pm 0,6^{b}$ & $11,2 \pm 2,1^{a}$ \\
\hline
\end{tabular}

Letras distintas entre grupos indicam diferença estatística significativa $(\alpha=0,05)$.

Os genes associados à resposta pró-inflamatória IFN- $\gamma$ e TNF- $\alpha$ apresentaram uma diminuição do valor de $\Delta$ CT em alguns tecidos dos animais dos grupos infectados por N. caninum, o que significa um aumento da expressão dos mesmos em resposta ao agente. A indução da expressão desses genes corresponde ao esperado na resposta a um parasito intracelular (INNES et al., 2007).

Estatisticamente o aumento da na expressão do gene IFN- $\gamma$ foi significativa $(\alpha=0,05)$ somente no linfonodo poplíteo contralateral à inoculação nos bezerros da raça Nelore. Verificou-se, entretanto, uma tendência de elevação na expressão deste gene no fígado e no linfonodo poplíteo ipsilateral à inoculação do parasito em ambas as raças, assim como no tecido de córtex cerebral dos holandeses.

O IFN- $\gamma$ está envolvido na ativação de macrófagos, aumentando a capacidade fagocitose e a apresentação de antígenos. Embora não significativa, houve uma discreta indução do gene iNOS, enzima associada a indução da produção de óxido nítrico envolvido na destruição do patógeno. $\mathrm{O}$ aumento da expressão de iNOS foi observado no linfonodo poplíteo contralateral e córtex cerebral dos Nelores infetcados e fígado dos holandeses infectados. 
Quanto à expressão de TNF- $\alpha$ foi detectada elevação em amostras de córtex cerebral dos bezerros Holandeses infectados e também uma elevação em amostras de fígado dos Nelores.

Quanto aos mediadores associados à modulação da resposta, foi observada uma inibição da expressão do gene TGF $\beta$-1 no tecido hepático dos Nelores infectados. O gene IL-10 apresentou variação somente no linfonodo poplíteo contralateral à inoculação dos bezerros Nelores. Essa variação foi uma discreta, mas significativa diminuição da expressão. Não foram detectadas variaçóes significativas nos demais tecidos analisados.

Não foram observadas variaçóes significativas na expressão de IL-4.

\section{Conclusão}

A expressão dos genes IFN- $\gamma$, IL-4, IL-10, TGF- $\beta 1$, iNOS, TNF- $\alpha$ e GAPDH foi detectada pela técnica do RT-PCR em tempo real em amostras de linfonodo poplíteo, fígado e córtex cerebral de bovinos das raças Holandesa e Nelore. A análise dos dados possibilitou a quantificação relativa dos genes e a diferenciação na expressão entre animais infectados e não-infectados por $N$. caninum e, dessa forma, a identificação de genes ativados em resposta à infecção.

No presente experimento, o nível de expressão do gene GAPDH apresentou-se relativamente constante entre os animais dos grupos infectado e controle e entre as raças Nelore e Holandesa e foi empregado como controle endógeno para a análise dos dados dos demais genes.

Embora os bezerros se apresentassem assintomáticos no sexto dia pós-infecção, foi possível detectar a resposta tecidual local predominantemente pró-inflamatória. As mudanças na expressão dos genes variaram de acordo com o tecido, isto é, foram observadas tanto a indução quanto a inibição da expressão que ocorreu em diversos graus de intensidade.

Os genes associados aos mediadores pró-inflamatórios (IFN- $\gamma$, TNF- $\alpha$ e à indução de enzimas associadas à atividade fagocitária (iNOS) foram os que apresentaram indução nos animais infectados em relação aos controles, o TGF- $\beta 1$ apresentou uma inibição em amostras de fígado nos Nelores e a expressão dos genes IL-4 e IL-10 se manteve praticamente inalterado.

O uso da técnica da RT-PCR em tempo real permitiu a detecção e a comparação da expressão de genes em diferentes tecidos de bovinos. Frente à escassez de reagentes espécie específicos, a quantificação da expressão de mRNA torna-se uma ferramenta adicional para a avaliação da atividade celular contra as infecçóes, monitoramento de vacinaçóes e ação de medicamentos.

\section{Agradecimentos}

Aos Srs. João A. Metzner, Antônio Santa Rosa e José Roberto Devitto pelos cuidados no manejo dos animais experimentais. Suporte financeiro da Fundação de Amparo à Pesquisa do Estado de São Paulo (FAPESP 05/01659-0). S. M. Gennari e R. M. Soares agradecem ao CNPq pela bolsa concedida.

\section{Referências}

AGUIAR, D. M. et al. Prevalence of anti-Neospora caninum antibodies in cattle and dogs from Western Amazon, Brazil, in association with some possible risk factors. Veterinary Parasitology, v. 142, n. 1-2, p. 71-77, 2006.

APPLIED BIOSYSTEMS. Guide to performing relative quantitation of gene expression using Real-Time quantitative PCR. 2004. Disponível em: <http://www3.appliedbiosystems.com/sup/gl/search. htm>. Acesso em: Jan. 2006.

BUSTIN, S. A. Quantification of mRNA using real-time reverse transcription PCR (RT-PCR): trends and problems. Journal of Molecular Endocrinology, v. 29, n. 1, p. 23-39, 2002.

BUSTIN, S. A. et al. Quantitative real-time RT-PCR - a perspective. Journal of Molecular Endocrinology, v. 34, n. 3, p. 597-601, 2005.

CORBELLINI, L. G. et al. Neosporosis as a cause of abortion in dairy cattle in Rio Grande do Sul, southern Brazil. Veterinary Parasitology, v. 103, n. 3, p. 195-202, 2002.

DUBEY, J. P.; SCHARES, G.; ORTEGA-MORA, L. M. Epidemiology and control of neosporosis and Neospora caninum. Clinical Microbiology Reviews, v. 20, n. 2, p. 323-367, 2007.

GENBANK: NIH Genetic Sequence Database. Disponível em: <http:// www.ncbi.nlm.nih.gov/Genbank/index.html>. Acesso em: Maio 2005.

GONDIM, L. F. et al. Seroprevalence of Neospora caninum in dairy cattle in Bahia, Brazil. Veterinary Parasitology, v. 86, n. 1, p. 71-75, 1999.

GUIMARĀES Jr, J. S. et al. Prevalence of Neospora caninum antibodies and factors associated with their presence in dairy cattle of the north of Paraná state, Brazil. Veterinary Parasitology, v. 124, n. 1-2, p. 1-8, 2004.

HEMPHILL, A. et al. Cellular and immunological basis of the host-parasite relationship during infection with Neospora caninum. Parasitology, v. 133, n. 3, p. 261-278, 2006.

INNES, E. A. et al. Comparative host-parasite relationships in ovine toxoplasmosis and bovine neosporosis and strategies for vaccination. Vaccine, v. 25, n. 30, p. 5495-5503, 2007.

INNES, E. A. et al. Interferon gamma inhibits the intracellular multiplication of Neospora caninum, as shown by incorporation of ${ }^{3} \mathrm{H}$ uracil. Journal of Comparative Pathology, v. 113, n. 1, p. 95-100, 1995.

INNES, E. A. et al. The host-parasite relationship in bovine neosporosis. Veterinary Immunology and Immunopathology, v. 108, n. 1-2, p. 29-36, 2005.

KHAN, I. A. et al. Neospora caninum: role for immune cytokines in host immunity. Experimental Parasitology, v. 85, n. 1, p. 24-34, 1997.

LONG, M. T.; BASZLER, T. V.; MATHISON, B. A. Comparison of intracerebral parasite load, lesion development, and systemic cytokines in mouse strains infected with Neospora caninum. Journal of Parasitology, v. 84, n. 2, p. 316-320, 1998.

MELO, D. P. et al. Prevalence of antibodies anti-Neospora caninum in bovines from Anápolis and Goiânia microregions, Goiás, Brazil. Revista Brasileira de Parasitologia Veterinária, v. 15, n. 3, p. 105-109, 2006.

MINERVINO, A. H. et al. Prevalence of Neospora caninum antibodies in cattle from Santarém, Pará, Brazil. Research in Veterinary Science, v. 84 , n. 2, p. 254-256, 2008. 
MUNHOZ, A. D. et al. Distribution of anti-Neospora caninum antibodies in dairy cows at Municipalities of Resende and Rio Claro in the State of Rio de Janeiro, Brazil. Revista Brasileira de Parasitologia Veterinária, v. 15, n. 3, p. 101-104, 2006.

OSHIRO, L. M. et al. Prevalence of anti-Neospora caninum antibodies in cattle from the state of Mato Grosso do Sul, Brazil. Revista Brasileira de Parasitologia Veterinária, v. 16, n. 3, p. 133-138, 2007.

PRIMER EXPRESS Software. Version 3.3. Foster City: Applied Biosystems, 2005. 1 CD-ROM.

RETTIGNER, C. et al. Survival, immune responses and tissue cyst production in outbred (Swiss white) and inbred (CBA/Ca) strains of mice experimentally infected with Neospora caninum tachyzoites. Veterinary Research, v. 35, n. 2, p. 225-232, 2004.
RITTER, D. M. et al. Immune factors influencing the course of infection with Neospora caninum in the murine host. Journal of Parasitology, v. 88 , n. 2, p. 271-280, 2002.

SEQUENCE DETECTION Software. Version 1.3: 7500 System SDS Software. Foster City: Applied Biosystems, 2004. 1 CD-ROM.

THELLIN, O. et al. Housekeeping genes as internal standards: use and limits. Journal of Biotechnology, v. 75, n. 2-3, p. 291-295, 1999.

YAMANE, I. et al. The inhibitory effect of interferon gamma and tumor necrosis factor alpha on intracellular multiplication of Neospora caninum in primary bovine brain cells. Parasitology, v. 62, n. 3, p. 347-351, 2000.

ZARLENGA, D. S.; HIGGINS, J. PCR as diagnostic and quantitative technique in veterinary parasitology. Veterinary Parasitology, v. 101, n. 3-4, p. 215-230, 2001. 